Vol. 44, N. 4 : pp. 419 - 423, December, 2001

ISSN 1516-8913 Printed in Brazil

\section{BRAZILIAN ARCHIVES OF BIOLOGY AND TECHNOLOGY}

AN INTERNATIONAL JOURNAL

\title{
Effect of Biofertilizers and Neem Oil on the Entomopathogenic Fungi Beauveria bassiana (Bals.) Vuill. and Metarhizium anisopliae (Metsch.) Sorok
}

\author{
Edson Hirose*; Pedro M. O. J. Neves; João A. C. Zequi; Luís H. Martins; Cristiane H. \\ Peralta $^{1}$ and Alcides Moino Jr. ${ }^{2}$. \\ ${ }^{1}$ Departamento de Agronomia, Universidade Estadual de Londrina, Caixa Postal 6001, 86051-970, Londrina - PR, \\ Brazil; ${ }^{2}$ Departamento de Entomologia, Universidade Federal de Lavras, Caixa Postal 37, 37200-000, Lavras - \\ $M G$, Brazil
}

\begin{abstract}
The in vitro fungitoxic effect of three biofertilizers, E.M.-4, Multibion ${ }^{T M}$ and Supermagro used in organic agriculture and the neem oil (Azadirachta indica A. Juss) on the entomopathogenic fungi Metarhizium anisopliae and Beauveria bassiana was studied. These products were mixed in a medium where the two fungi were inoculated, and germination, vegetative growth and conidiogenesis were assessed. The biofertilizers Supermagro and E.M.- 4 showed to be less toxic for the two fungi whereas Multibion ${ }^{\mathrm{TM}}$ caused major inhibition on M. anisopliae, with reductions in germination $(-37.74 \%)$, colony diameter $(-30.26 \%)$ and conidiogenesis $(-42.62 \%)$. Neem oil promoted a larger negative effect on B. bassiana, inhibiting germination (-45.27\%), colony diameter (-36.62\%) and conidiogenesis $(-84.93 \%)$.
\end{abstract}

Key words: Organic Agriculture, Entomopathogenic Fungi, Toxic Effect

\section{INTRODUCTION}

The production of organic food requests for methods that use non-chemical inputs. In this production system, pests are essentially managed by biological agents, where the entomopathogenic fungi, Beauveria bassiana (Bals.) Vuill and Metarhizium anisopliae (Metsch.) Sorok. are considered important factor of insect population reduction. So, there is the necessity of entomopathogens conservation, if it occurs naturally, are applied or introduced with the objective of controlling insects. However, for their conservation, it is important to know the pathogens compatibility with other agricultural practices to avoid losses of control efficiency.

Several biofertilizers and insecticides used in organic agriculture might affect the action of entomopathogenic fungi in the same way as do the chemical products. The use of incompatible chemical products may inhibit the development and reproduction of these pathogens, affecting pest control (Malo 1993, Duarte et al. 1992, Anderson and Roberts 1983). On the other hand, the use of selective products is an important strategy in IPM (Integrated Pest Management). In some cases, compatible products may be associated with entomopathogenic fungi, increasing control

* Author for correspondence 
efficiency (Moino and Alves 1998, Quintela and McCoy 1998).

In general, biofertilizers or insecticides used in organic agriculture are not very standardized due to their home made nature, being prepared by farmers themselves or by small companies. Thus, the variability of these products composition might be quite large. However, with the recent increase in organic food production, and in the use of products in systems where the entomopathogenic fungi B. bassiana and M. anisopliae are also used, a study on the compatibility among them is needed.

The present study deals with the compatibility of three biofertilizers and neem oil with $B$. bassiana and M. anisopliae.

\section{MATERIALS AND METHODS}

Following strains were used: B. bassiana - CG 252 (Embrapa - Cenargen) and M. anisopliae - strain CB 38 (Instituto Biológico de Campinas). Conidia were cultured in a PDA (potato-dextrose-agar) medium. The treatments were: E.M.-4 (Fundação Mokiti Okada - MOA), Supermagro (produced according to patterns provided by Instituto Biodinâmico de Desenvolvimento Rural - IBD), Multibion $^{\mathrm{TM}}$, and neem oil (Azadirachta indica A. Juss). The products concentrations in aqueous solution were the average recommendation (AR) for field application in $100 \mathrm{l} / \mathrm{ha}$, in the following percentages: E.M.-4 (AR 3\%), Multibion ${ }^{\mathrm{TM}}$ (AR $5 \%$ ), Supermagro (AR 3\%) and neem oil (AR $2 \%)$.

Germination assessment: Products were dissolved in sterile water plus $0.02 \%$ of Tween 20 , containing $B$. bassiana and $M$. anisopliae conidia mixing separately. One hour after, $0.5 \mathrm{ml}$ aliquot from each suspension was spread in four Petri dishes water-agar medium, with a Drigalski spatula. The dishes were incubated in a chamber (temperature of $25 \pm 1^{\circ} \mathrm{C}$, and of $12 \mathrm{~h}(\mathrm{~L}) / 12 \mathrm{~h}$ (D) photoperiod). After 24 hours, the percentage of germinated conidia was quantified.

Vegetative growth and conidia production assessments: Biofertilizers were filtered with milipore filters $(0.2 \mu \mathrm{m})$ to remove contaminant microorganisms. Samples were diluted in a complete medium (Alves et al. 1998a) plus streptomycin $(0.5 \mathrm{~g} / \mathrm{l})$ at $45 \pm 5^{\circ} \mathrm{C}$ and turned into Petri dishes. After medium solidification, the fungi were inoculated with platinum loop at three points per dish (five dishes/treatment), and incubated in a chamber (temperature of $25 \pm 1^{\circ} \mathrm{C}$ and $12 \mathrm{~h}$ (L) / $12 \mathrm{~h}$ (D) photoperiod).

Eight days after inoculation, colony diameters were assessed and ten central colony disks (2.27 $\mathrm{cm}^{2}$ ) from each treatment were collected for conidia quantification. The option for a standard sample colony area in relation to all colony area for conidia production assessment was made because the expression of the differences in conidia production was more evident. Each disk was placed in a glass tube and the conidia were suspended in $10 \mathrm{ml}$ of sterile water containing $0.02 \%$ Tween 20 and quantified using a Neubauer chamber.

The assays were in complete randomized design. Data were submitted to ANOVA and means were compared by the Tukey test $(\mathrm{P} \leq 0.05)$.

Compatibility calculation: Compatibility was calculated according to Alves et al. (1998b), as follows:

$$
\mathrm{T}=\frac{20(\mathrm{VG})+80(\mathrm{ESP})}{100}
$$

In this model, values for vegetative growth (VG) and esporulation (ESP) are given in relation to the control $(100 \%)$. Where $\mathrm{T}=0$ to $30=$ very toxic; 31 to $45=$ toxic; 46 to $60=$ moderately toxic; $>60=$ compatible.

\section{RESULTS AND DISCUSSION}

Significant reduction was observed in the germination, vegetative growth and conidia production of $M$. anisopliae in all treatments, except Supermagro, in which the conidia germination was similar to the control (Table 1). Multibion $^{\mathrm{TM}}$ resulted maximum negative effect, with reductions in germination $(22.7 \%)$, vegetative growth $(43.59 \%)$ and conidiogenesis $(83.53 \%)$. This reduction was probably due to the presence of organic acids (acetic, propanoic, butiric, malic, succinic and tartaric) in the product (data in the label of the product). Studying the effects of organic acids on M. anisopliae, Li and Holdom 
(1995) concluded that the acetic and malic acids reduced vegetative growth and conidiogenesis.

E.M.-4 and neem oil showed the same effect on conidia germination with reductions of $21.28 \%$ and $17.26 \%$. The inhibition caused by neem oil agreed with the results obtained by Aguda et al. (1986) and Gonzalez et al. (1996), which verified the negative effect caused by neem on $M$. anisopliae germination and conidiogenesis.

In relation to the vegetative growth of $M$. anisopliae, Supermagro and E.M.-4 showed the same reduction level. Neem oil remained in an intermediate level. For conidia production E.M.-4, Supermagro and neem oil caused reductions around $50 \%(49.65 \%, 56.94 \%$ and $54.35 \%)$, respectively (Table 1$)$.

For $B$. bassiana, neem oil caused the largest reduction in germination (45.27\%), vegetative growth $(36.62 \%)$ and conidiogenesis (84.93\%) (Table 2). Bajan et al. (1998) also observed a reduction in the vegetative growth of $B$. bassiana colonies caused by a commercial formulation of neem. Multibion ${ }^{\mathrm{TM}}$ did not show statistical difference in relation to neem oil and caused reductions in germination $(37,74 \%)$, colony diameter $(30.26 \%)$ and conidiogenesis $(42.62 \%)$. Probably the same organic acids that might have affected $M$. anisopliae development caused the negative effect on $B$. bassiana.

Table 1 - Germination percentage (mean $\pm \mathrm{SD})$, colony diameter (mean $\pm \mathrm{SD})$ and conidia number $(\mathrm{mean} \pm \mathrm{SD})$ of Metarhizium anisopliae strain CB38 (temperature of $25 \pm 1^{\circ} \mathrm{C}$ and $12 \mathrm{~h}$ (L) / $12 \mathrm{~h}$ (D) photoperiod) with different treatments.

\begin{tabular}{|c|c|c|c|c|c|c|c|}
\hline \multirow[t]{2}{*}{ Treatments } & \multicolumn{3}{|c|}{$\begin{array}{l}\text { Germination percentage } \\
\qquad(\mathrm{n}=4)\end{array}$} & \multicolumn{2}{|c|}{$\begin{array}{l}\text { Colony Diameter } \\
(n=15)\end{array}$} & \multicolumn{2}{|c|}{$\begin{array}{l}\text { Conidia Number } \\
(n=10)\end{array}$} \\
\hline & $(\%)^{(1)}$ & & (\%)reduction & $(\mathrm{cm})$ & (\%)reduction & $\left(\mathrm{n} \times 10^{7}\right)^{(1)}$ & (\%)reduction \\
\hline Control & $84.6 \pm 2.73$ & $\mathrm{a}^{(2)}$ & 0.00 & $4.1 \pm 0.21 \mathrm{a}$ & 0.00 & $42.5 \pm 15.66 \mathrm{a}$ & 0.00 \\
\hline E.M.-4 & $66.6 \pm 2.07$ & $\mathrm{~b}$ & -21.28 & $3.8 \pm 0.16 \quad b$ & -9.19 & $21.4 \pm 12.70 \quad b$ & -49.65 \\
\hline Multibion ${ }^{\mathrm{TM}}$ & $65.4 \pm 6.99$ & $\mathrm{~b}$ & -22.70 & $2.3 \pm 0.27$ & -43.59 & $7.0 \pm 5.06$ & -83.53 \\
\hline Supermagro & $87.5 \pm 1.16$ & $\mathrm{a}$ & +3.43 & $3.6 \pm 0.14 b$ & -12.23 & $18.3 \pm 6.74 \mathrm{~b}$ & -56.94 \\
\hline Neem oil & $70.0 \pm 10.69$ & $\mathrm{~b}$ & -17.26 & $2.6 \pm 0.08 \quad \mathrm{c}$ & -36.87 & $19.4 \pm 2.43 \quad b$ & -54.35 \\
\hline
\end{tabular}

(1) Original data.

(2) Means followed by different letters within each column are significantly different $(\mathrm{P} \leq 0.05)$ from control treatment; Tukey's studentized range test.

Table 2 - Germination percentage (mean \pm SD), colony diameter (mean \pm SD) and conidia number $(m e a n \pm S D)$ of Beauveria bassiana strain CG252 (temperature of $25 \pm 1^{\circ} \mathrm{C}$ and $12 \mathrm{~h}(\mathrm{~L}) / 12 \mathrm{~h}$ (D) photoperiod) with different treatments.

\begin{tabular}{|c|c|c|c|c|c|c|c|}
\hline \multirow[t]{2}{*}{ Treatments } & \multicolumn{3}{|c|}{$\begin{array}{l}\text { Germination percentage } \\
(\mathrm{n}=4)\end{array}$} & \multicolumn{2}{|c|}{$\begin{array}{c}\text { Colony Diameter } \\
(\mathrm{n}=15)\end{array}$} & \multicolumn{2}{|c|}{$\begin{array}{c}\text { Conidia Number } \\
(\mathrm{n}=10)\end{array}$} \\
\hline & $(\%)^{(1)}$ & & (\%)reduction & $(\mathrm{cm})$ & (\%)reduction & $\left(\mathrm{n} \times 10^{7}\right)^{(1)}$ & (\%)reduction \\
\hline Control & $93.0 \pm 2.54$ & $\mathrm{a}^{(2)}$ & 0.00 & $3.1 \pm 0.17 \mathrm{a}$ & 0.00 & $190.5 \pm 50.82 \mathrm{a}$ & 0.00 \\
\hline E.M.-4 & $75.8 \pm 3.00$ & $\mathrm{~b}$ & -18.49 & $2.7 \pm 0.38 \quad b$ & -12.20 & $127.5 \pm 60.58 \mathrm{~b}$ & -33.07 \\
\hline Multibion ${ }^{\mathrm{TM}}$ & $57.9 \pm 4.66$ & $\mathrm{c}$ & -37.74 & $2.2 \pm 0.27$ & -30.26 & $109.3 \pm 25.27 \quad b$ & -42.62 \\
\hline Supermagro & $81.8 \pm 4.86$ & $\mathrm{~b}$ & -12.04 & $2.8 \pm 0.23 \mathrm{ab}$ & -9.34 & $139.2 \pm 19.28 \mathrm{ab}$ & -29.93 \\
\hline Neem oil & $50.9 \pm 3.74$ & $\mathrm{c}$ & -45.27 & $2.0 \pm 0.20 \mathrm{~cd}$ & -36.62 & $28.7 \pm 18.33 \quad \mathrm{c}$ & -84.93 \\
\hline
\end{tabular}

\footnotetext{
(1) Original data

(2) Means followed by different letters within each column are significantly different $(\mathrm{P} \leq 0.05)$ from control treatment; Tukey's studentized range test.
} 
The biofertilizer Supermagro caused the lowest reduction levels for $B$. bassiana with no statistical difference in vegetative growth and conidia production in relation to the control. E.M.-4 reductions were not different from Supermagro treatment; however, they were statistically different from the control.

According to the model of Alves et al. (1998b), E.M.-4 and Supermagro were compatible with $B$. bassiana, Multibion ${ }^{\mathrm{TM}}$ was moderately toxic and neem oil was toxic. For $M$. anisopliae, Multibion $^{\mathrm{TM}}$ was very toxic and Supermagro, E.M.-4 and neem oil were moderately toxic (Table $3)$.

The formula proposed by Alves et al. (1998b) represented in an appropriate way the toxic effect on the entomopathogenic fungi in vitro. These studies have the advantage of exposing the pathogen to the maximum action of the chemicals, which do not occur under field conditions. Thus, when the treatment is compatible in vitro, there are strong evidences of its selectivity under field conditions. However, a high toxicity in vitro does not always mean that the same will happen in the field (Alves et al. 1998b). In addition, under field conditions, vegetative growth inhibition may not be a good indication of fungicidal effects such as spore viability (Loria et al. 1983). This formula did not consider the treatment effect on germination, nevertheless, the results showed that these biofertilizers and the neem oil should be used with restrictions.

Table 3 - "T" values and compatibility classification of the biofertilizers EM-4, Multibion ${ }^{\mathrm{TM}}$, Supermagro and the neem oil on B. bassiana - strain CG252 and M. anisopliae - strain CB38.

\begin{tabular}{lcccc}
\hline \multirow{2}{*}{ Treatments } & \multicolumn{2}{c}{ Values of "T" } & \multicolumn{2}{c}{ Classification } \\
\cline { 2 - 5 } & \multicolumn{1}{c}{ B. bassiana } & M. anisopliae & B. bassiana & M. anisopliae \\
\hline & 71.10 & 58.44 & $\mathrm{C}^{2}$ & MT \\
E.M.-4 & 59.85 & 24.46 & MT & VT \\
Multibion $^{\mathrm{TM}}$ & 76.59 & 52.00 & $\mathrm{C}$ & MT \\
Supermagro & 24.73 & 49.14 & $\mathrm{~T}$ & MT \\
Neem oil & & & & \\
\hline
\end{tabular}

\footnotetext{
${ }^{1}$ Alves et al. (1998b)

${ }^{2} \mathrm{C}=$ compatible, $\mathrm{MT}=$ moderately toxic, $\mathrm{T}=$ toxic, $\mathrm{VT}=$ very toxic
}

Under field condition, compatibility germination should be considered as the most important factor (Malo 1993; Anderson and Roberts 1983) due to the fact that pathogens infect insects through conidia germination by ingestion or contact. The survival of inoculum of the entomopathogenic fungi in the field is made by conidia. In the beginning of the epizootic, the conidia are responsible for the first disease focuses (Alves and Lecuona, 1998).

Thus, if germination inhibition occurs, the pathogen control efficiency will be affected by contact of product. When reduction in B. bassiana germination was analyzed, neem oil and Multibion $^{\mathrm{TM}}$ were found to cause the highest reduction levels and should never be used in mixtures with this entomopathogenic fungi or in pest control strategies where these fungi could be applied or could be an important natural pest population reduction factor. Which suggestion, the formula proposed by Alves et al. (1998b) should consider the reduction in conidia germination an important factor in compatibility.

Information about compatibility among entomopathogenic fungi and products used in organic agriculture, like fertilizers and insecticides, is scarce. Field studies with the application of products together with pathogens can provide extra information to that obtained by this study to help in the development of strategies for handling plagues in organic agriculture.

\section{ACKNOWLEDGEMENTS}

This research was financial supported by CAPES. The authors thank Sueli Martinez (Instituto Agronomico do Paraná, Londrina Paraná, Brazil) for the neem oil supply, Cesar Abraão (Secretaria da Agricultura de Londrina) for the biofertilizers 
Supermagro and Multibion ${ }^{\mathrm{TM}}$ supply, Inês Cristina B. Fonseca (Universidade Estadual de Londrina) for the support in the statistical analysis, and Mauricio U. Ventura (Universidade Estadual de Londrina) for reviewing this manuscript.

\section{RESUMO}

Verificou-se o efeito fungitóxico in vitro de três biofertilizantes: E.M.-4, Multibion ${ }^{\circledR}$, Supermagro e do óleo de nim (Azadirachta indica A. Juss), utilizados na agricultura orgânica, sobre os fungos entomopatogênicos Metarhizium anisopliae e Beauveria bassiana. Estes produtos foram misturados em meio de cultura, onde os dois fungos estavam inoculados. Avaliou-se germinação, crescimento vegetativo e conidiogênese. Os produtos Supermagro e E.M.-4 foram os menos tóxicos para os dois fungos, Multibion ${ }^{\circledR}$ causou maior inibição em $M$. anisopliae, com reduções na germinação ($37,74 \%)$, diâmetro de colônias $(-30,26 \%)$ e conidiogênese $(-42,62 \%)$ enquanto que o óleo de nim. provocou maior efeito negativo sobre $B$. bassiana, inibindo a germinação $(-45,27 \%)$, diâmetro de colônias $(-36,62 \%)$ e conidiogênese ($84,93 \%)$.

\section{REFERENCES}

Aguda, R. M.; Rombach, M. C. and Shepard, B. M. (1986), Effect of "neem" oil on germination and sporulation of the entomogenous fungus Metarhizium anisopliae, Int. Rice Res. Newsletter, 11, 34-35.

Alves, S. B.; Almeida, J. E. M.; Moino Jr., A. and Alves, L. F. A (1998a), Técnicas de laboratório. InControle microbiano de insetos, ed. S.B. Alves. Fealq, São Paulo, pp.637-712.

Alves, S. B.; Moino Jr., A. and Almeida, J. E. M. (1998b), Produtos fitossanitários e entomopatógenos. In- Controle microbiano de insetos, ed. S.B. Alves. Fealq, São Paulo, pp.217-238.

Alves, S. B. and Lecuona, R. E. (1998), Epizootiologia aplicada ao controle microbiano de insetos. InControle microbiano de insetos, ed. S. B. Alves. Fealq, São Paulo, pp.97-170.
Anderson, T. E. and Roberts, D. W. (1983), Compatibility of Beauveria bassiana Isolates with Insecticide Formulations Used in Colorado Potato Beetle (Coleoptera: Chrysomelidae) Control. J. Econ. Entomol., 76, 1437-1441.

Bajan, C.; Kmitowa, K. and Popowska Nowak, E. (1998), Reaction of various ecotypes of entomopathogenic fungus Beauveria bassiana to the botanical preparation NEEM ${ }^{\mathrm{TM}}$ and pyrethroid Fastak. Arch. of Phytopathol. and Plant Protection, 31, 369-375.

Duarte, A.; Menendez, J. M. and Triguero, N. (1992), Estudio preliminar sobre la compatibilidad de Metarhizium anisopliae com algunos plaguicidas quimicos. Rev. Baracoa, 22, 31-39.

Li, D. P. and Holdom, D. G. (1995), Effects of nutrients on colony formation, growth, and sporulation of Metarhizium anisopliae (Deuteromycotina, Hyphomycetes). Journal of Invertebr. Pathol., 65, 253-260.

Loria, R.; Galaini, S. and Roberts, D. W. (1983), Survival of inoculum of the Entomopathogenic Fungus Beauveria bassiana as Influenced by Fungicides. Environ. Entomol., 12, 1724-1726.

Gonzalez, D. M. E.; Valbuena, P. B. F.; Rivera, M. A.; Bustillo, P. A. E. and Chaves, B. (1996), Viabilidad del hongo Metarhizium anisopliae en mezcla con agroquimicos, Rev. Colomb. de Entomol., 22, 31-36.

Malo, A. R. (1993), Estudio sobre la compatibilidad del hongo Beauveria bassiana (Bals.) Vuill. con formulaciones comerciales de fungicidas $\mathrm{e}$ insecticidas. Rev. Colomb. de Entomol., 19, 151-158.

Moino Jr., A. and Alves, S. B. (1998), Efeito de Imidacloprid e Fipronil sobre Beauveria bassiana (Bals.) Vuill. E Metarhizium anisopliae (Metsch.) Sorok. e no Comportamento de Limpeza de Heterotermes tenuis (Hagen). An. Soc. Entomol. Brasil., 27, 611-619.

Quintela, E. D. and McCoy, C. W. (1998), Synergistic Effect of Imidacloprid and Two Entomopathogenic Fungi on the Behavior and Survival of Larvae of Diaprepes abbreviatus (Coleoptera: Curculionidae) in Soil. J. Econ. Entomol., 91, 110-122.

Received: June 30, 2000; Revised: April 11, 2001; Accepted: May 02, 2001. 